\title{
The Reasons for the Wide-Spread of White Lotus in Dong Xiang County in the Mid-Qing Dynasty
}

\author{
Meng Wang \\ School of Politics and Law, Sichuan University of Arts and Science, Dazhou, China \\ Email: 312142477@qq.com
}

How to cite this paper: Wang, M. (2020). The Reasons for the Wide-Spread of White Lotus in Dong Xiang County in the Mid-Qing Dynasty. Advances in Historical Studies, 9, 13-19.

https://doi.org/10.4236/ahs.2020.92002

Received: February 28, 2020

Accepted: May 15, 2020

Published: May 18, 2020

Copyright ( 2020 by author(s) and Scientific Research Publishing Inc. This work is licensed under the Creative Commons Attribution International License (CC BY 4.0).

http://creativecommons.org/licenses/by/4.0/

\section{(c) (i) Open Access}

\begin{abstract}
There are many causes for the White Lotus's wide-spread in Dong Xiang county in Sichuan province in the mid-Qing Dynasty. For example, Dong Xiang county is mountainous; there are more forests than arable land in its territory. It is impossible to provide the growing population with farm produce by means of the local poor soil and backward agricultural production. Moreover, it can't provide extra resources to support the large-scale development of industry and commerce, therefore a large number of people are separated from social production. As a result, these refugees have become important targets for the spread of the White Lotus. Buddhism, Taoism and Confucianism are all existing in Dong Xiang county. And in the meantime, witchcraft is generally advocated by the local residents, so this provided the ideological base for the spread of the White Lotus. The religious idea of Doomsday promoted by the White Lotus is very attractive to both the rich and the poor. The corruption of grass-roots officials and their endless extortion forced more and more poor people to join the White Lotus.
\end{abstract}

\section{Keywords}

The White Lotus, Dong Xiang County, The Mid-Qing Dynasty, Doomsday, Refugees

\section{The Influence of Geographical Environment}

In the mid-Qing Dynasty, the overall social environment was relatively stable, this led to an unprecedented increase in the population of China. The huge population had gradually exceeded the limit of the ancient agricultural economy, so the Qing Empire gradually fell into the resource dilemma which more people and less land. The living resources available to the people at the bottom of the 
Qing Empire were gradually decreasing, most of them can only maintain low production and consumption, and they barely had adequate food and clothing all the year. It was more difficult for them who lived in the area of Qinba Mountains, compared with the poor in other places because of the special geographical environment where they lived. The social contradictions in Dongxiang County and other places near it became more acute in general.

Dongxiang County is located in the northeastern Sichuan Province. There are so many high mountains and dense forests, meanwhile most of soils are very poor within its territory and large levels of land available for reclamation are rare. There are endless mountains in Dongxiang County, some of those mountains are very high and steep, of which less than one tenth of the fields, and rocky mountains, cultivate land was very little ((Qing Dynasty) Xu, 1976). In Dongxiang County, not only the cultivation conditions are very poor, but also the level of agricultural cultivation is relatively low. Most of the local agricultural land is rain-fed and subject to the vagaries of weather. The construction of water conservancy irrigation facilities is not satisfactory, and the ability to resist natural disasters such as floods and droughts is relatively fragile. According to the records of Jia Qing, if the terrain is slightly higher, the fields in the upper rivers will not be able to get large-scale irrigation due to out-dated irrigation technologies. For the peasants in Dongxiang County, most of them basically lived on the weather, once facing the continuous rising prices; they can only keep a very hard life because of their low income and the poor harvest.

The contradiction between a growing population and less land became increasingly prominent during the reign of Jia Qing. The poor in Dongxiang County had to plough virgin fields in the mountains, they had no choice but to destroy the forests and plant a large number of drought-tolerant crops such as potatoes and sweet potatoes in order to survive. The peasants basically satisfied their hunger at the time of harvest relying on this kind of extensive cultivation. However, there will be no harvest because of natural disasters such as drought floods and other disasters. In this case, a large number of farmers will immediately slide into the hungry, struggling to stay alive. Partly as a result of the unfavorable natural environment in the mountainous areas, the livelihoods of a large number of landless people in Dongxiang County are mostly seasonal economic labor. But this seasonal work brings bigger risks and uncertainties to the survival of famers, industries such as harvesting are too dependent on nature. For example, output of certain products is often very unstable due to the changes in climate and hydrological conditions. Although Qinba Mountain area is rich in wood v coal, iron and other resources, it is difficult for local agriculture to produce more surplus resources to support a large number of non-agricultural population to join the industry and commerce. One of the most important reasons is the contradiction between the barren land and the rapid growth of the population.

Although the Ba shan Lao lin area is not an ideal farming area, which made it 
a paradise for the jobless and criminals due to the high mountains and dense forests. Dongxiang County is just located at the border of several provinces such as Sichuan and Shanxi, which led to the weak social control over this area by the Qing government. In the early Qing Dynasty, the prefectures and counties established in the northeastern Sichuan area mostly had large jurisdictions. What's interesting, their jurisdictions where there are overlapping. These places have turned into the lawless area. In the ancient agricultural society, the special geographical environment of the $\mathrm{Ba}$ shan Lao lin area was indeed extremely unfavorable for local social governance.

Yan Ruyu who lived that era writed some detail about this situation in his writings. "The large ones of prefectures and counties in this area are as wide as one or two thousand li (Qing Dynasty) radius, even the small ones are also a-s small as five or six hundred li radius. The area under the jurisdiction of the local officials is too vast, the military organ stationed here like Yingxun (one of the military establishment in Qing Dynasty) are very sparse. Once something happened in one place such as a criminal case, it usually took several days for local officials to receive the news and then they reached the scene of the crime until a few days later. The criminals had already run away when the government investigators arrived. It was very difficult to catch them because of local geographic environment. And it is common for local people to shield each other from punishment; this increases the difficulty of solving the case. In addition, each province has its own border, local officials cannot cross the border to exercise their jurisdiction though the jurisdictions of some counties coincide. The outlying areas are hundreds to one thousand miles from the provincial capital, the transportation between two places is poor. Nevertheless, the case is sometimes related to the two provinces, it will take months for officials to travel between the two places for consultation" ((Qing Dynasty) Yan, 2018).

The governance dilemma mentioned above had not been changed after the addition of more counties in the middle of the Qing Dynasty. To take Dongxiang County as an example, it lies in the northeastern Sichuan Province, bordering Da County and Taiping County.

In administrative divisions, it borders Da County and Taiping County, where these three counties cross each other. The consequence is that areas covered by all three counties become the places where no one governer. Some bandits, refugees and so on took the opportunity to gather together in these areas, they robbed the local people from time to time, killed passing merchants and took goods away, and these people had seriously endangered local social stability and destroied the basic order of the government. A large number of people who separated from social production provided an excellent target for the spread of White Lotus in Dongxiang County.

\section{Witchcraft-Worship}

In ancient China, it was not easy for the poor living at the bottom of the society 
to solve their own food and clothing, once they got sick, they usually didn't have enough money to pay for a doctor. So they seldom called on the doctors whenever the poor suffered from diseases and epidemics. The patients were accustomed to invite sorcerers to cure diseases with witchcraft. Of course, this method really saved money especially for the poor. And in general this custom was popular in the mountainous area. There were so many people living in remote areas of southwestern Sichuan believed in witchcraft because of poverty and backwardness.

Bashu, as the birthplace of Taoism, the belief in Taoism had never been severed. It also incorporated the local inherent witchcraft to form a unique superstition custom in the process of its long-lasting and continuous evolution. This unique belief was favored by the local poor people because it can "cure diseases and drive evil". A variety of religions, superstitions and customs were mixed in Dongxiang County, so witchcraft was more prevalent. Local people usually believed witch, their beloved someones were Duan gong. The people especially the poor didn't go to the doctor or take medicine when they were sick, they liked to get Duan gong to cure the disease. Once healed, Duan gong was regarded as a god. This custom was forbidden by the government, but it was useless ((Qing Dynasty) Xu, 1976, Volume 29).

The customs of Dongxiang County can be analyzed by the number of different religious temples built. There were twenty-one Taoist temples built in the county, including Yuan di temple, San qing temple and Chun yang temple in the Qing Dynasty. In addition, there were more Buddhist temples in Dongxiang County. There were still two hundred and eighteen temples in the county even in the second year of the Republic of China (1913) (Editorial Committee of Xuanhan County annals of Sichuan Province, 1994).

The local folk customs like coexistence of Buddhism, Taoism and Witches in Dongxiang County are very suitable for the development of White Lotus society. Because the doctrine of White Lotus itself is relatively miscellaneous, it absorbs the ideas of multiple denominations just including the Confucianism, Buddhism, Taoism and the witch culture.

It is precisely because of the enclosed geographical environment and the prosperity of witchcraft customs that the development of local education is very poor. In other words, this situation hinders the further development of education in Dongxiang County. There was no Jinshi in Dongxiang County throughout the Qing Dynasty. The number of Jinshi in the entire northeastern Sichuan area was also lower than the average level Sichuan, which was incomparable to Jiangnan where culture and education were prosperous. The backward cultural and educational undertakings in the mountainous areas, in turn, led to poor and ignorant of local villagers. Moreover, there was no strong restraint and restriction of Confucian ethical order here, the local people were susceptible to incitement by missionaries, so they blindly followed the crowd and joined religious organizations like the White Lotus. 


\section{The Attraction of the White Lotus}

The White Lotus worshiped the "the virgin old mother" and "the Maitreya Buddha ", its followers preached that Maitreya Buddha would transform the old world in the near future. And the White Lotus society used the eight-character "zhen kong jia xiang, wu sheng lao mu" as mantras, admittedly the poor could get a certain sustenance in the spirit from its doctrine. And the White Lotus also advocated "the wealth gained throughout religion are shared equally", "to help each other, not afraid of death when in trouble", "travel around the world without money". These ideas are indeed attractive to the local poor people because they would like to change their own destiny in this world, and be liberated from the miserable life. Because of this, more and more people joined the White Lotus.

It has to be said that the idea of "doomsday" accepted by local people is very easily, and especially it is extremely poor and backward in Dongxiang County. Some doctrines of the White Lotus are strengthened in the display of various mystical magic. Missionaries often create some magic or illusion to make believers believe that the white towels or invocatings that they have blessed have some kind of mysterious power, which can not only avoid disasters, but also avoid harmed by swords. This kind of propaganda is very effective and lots of poor are attracted to join the White Lotus. The heads of the congregation also taught the congregation incantations, telling them that they could acquire certain mystical powers by reciting them. In addition, these leaders have also used various visions to display the power of gods. For example, denghua is as big as a dou, dustpan driving clouds, the bench turned into a horse. Through this method, not only the church members keeped with great reverence for the leaders, but also the great power of the religion and gods they believed have been showed off. In this way, the believers of the White Lotus are more convinced that the gods they believed such as Maitreya Buddha will be able to protect them when they fall into disaster in the future. The propagandists made people believe that when the end of the world came, their followers would be able to avoid evil and enjoy the bliss.

In addition, the believers can not only avoid disasters themselves, but also they can trick others into paying the Geng jiqian and pocketing the wealth after they have joined the White Lotus and learned the Lingwen. This way of accumulating wealth is quickly, it has great appeal to the poor people. According to what Wang San huai said, he was one of the heads of the White Lotus in Dongxiang County, "Later, I went to treat them in other people's homes and to teach them the mantra later, I got some Geng jiqian by this means" (Chinese Academy of Social Sciences, 1981: p. 65).

Most of the believers are also the poor, the reason why they give Geng jiqian to the heads is inseparable from the targeted propaganda of the White Lotus. The prophet of the White Lotus declared that "whoever joins the religion will be free from all disasters caused by flood, fire and wars". Although many poor people are in a difficult situation, they are used to live in fate and believe in reincarnation, it is reasonable for them to take out some money to save their lives and 
avoid misfortunes. Moreover, the White Lotus as a folk faith organization, in many cases, when the believers confront with disputes and contradictions, the organizers will also lead them to struggle, and the local government is often the object they fight against. This practice has increased the prestige of the White Lotus among the local people.

The amount of money contributed by the White Lotus members is sometimes even recorded in a notebook. In the future, these records will be used to award people. Of course, the person who has paid more money, more senior official position will be promised to him. However, this really confuses and attracts a group of persons who can't be an official but wealthy. For example, Nie Jie ren who had a lot of lands in Hubei, he contributed a big sum of money and some grain, so he was promised to be Zong du (an official in Qing Dynasty). "According to the confessions from Nie Jie ren, Zhang Zheng mo said to him there would be black wind and countless dead people in March of next year. He finally persuaded me to join the White Lotus because I also hoped to protect myself from disasters as a believer. And he also said that everyone who wanted to join the White Lotus should give some money to the organiziters, then passing the wealth accumulated on to Li Quan er. There would be different official positions for believers according to the amount of money everyone contributed recorded in the books after the uprising is successful. I wanted to be an official, so I took out one hundred liang (Qing Dynasty) silver to Liu Sheng cai. Because I donated a lot of money, I would be able to Zong du in the future" (Chinese Academy of Social Sciences, 1981: pp. 1-2).

The White Lotus just took advantage of the psychology that the rich wanted to avoid disaster, the poor coveted wealth, so it attracted a large number of people to join.

\section{Corruption of Grass-Roots Officials}

There were a large number of migrants in the area of Dongxiang County. In addition to building sheds and renting the landlord's land for farming in the mountains, they can also be employed in iron or paper mills, etc. In this way, they can earn meagre wages in order to maintain themselves and their family's survival. However, during the Qian jia period of the Qing Dynasty, grass-roots officials were corrupt and lots of corrupt officials were very rampant. In this way, the migrants not only have to suffer the cruel exploitation of the landlords and factory owners, but also withstand the extortion of corrupt officials and bullies, so their life became more difficult. Desperate refugees were eager to change the plight in their life, their longing for the afterlife had become extremely strong, so they have become the main target of spread of the White Lotus.

\section{Conclusion}

Dongxiang County is mountainous and there is not much arable land, the local agricultural production level is also extremely backward. So it's beyond the ca- 
pacity of the land owning to the aggravation of population growth. In addition, the traditional industrial and commercial development is slow and cannot accommodate so much surplus labor. As a result, these landless people drifted through the high mountains and dense forests, providing potential believers for the spread of the White Lotus. And the folk custom which Confucianism, Buddhism Taoism and witchcraft are coexisting in Dongxiang County provides a favorable ideological environment for the spread of the White Lotus.

Finally, the powerful temptation of the White Lotus doctrine, the corruption of officials in the mid-Qing period, the extortion and blackmail by local officials further promoted the wide-spread of the White Lotus.

\section{Founding}

This article is one of the achievements of the project of the Regional Cultural Research Center of China West Normal University in 2019. The project is" the research of Luo Si ju and the White Lotus uprising in Northeast Sichuan" (QYYJC1904).

\section{Conflicts of Interest}

The authors declare no conflicts of interest regarding the publication of this paper.

\section{References}

Chinese Academy of Social Sciences (1981). Information on the White Lotus Rebellion in Five Provinces in the Mid Qing Dynasty (Volume 5) Nanjing: Jiangsu People's Publishing House.

Editorial Committee of Xuanhan County Annals of Sichuan Province (1994). Xuanhan County Annals (pp: 873-874). Chengdu: South University of Finance and Economics Press.

Xu, C. M. (1976). Dongxiang Annals (Volume 14). Taipei: Cheng Wen Publishing.

Yan, R. Y. (2018). Preparation of Three Provinces Border Defense (Volume 14). Xi'an: Xi'an JiaoTong University Press. 